\title{
Pathogenesis of chronic Chagas' myocarditis
}

Department of Pathology, Faculdade de Medicina de Ribeirão Preto Universidade de São Paulo - São Paulo, Brazil

The pathogenesis of chronic Chagas' myocarditis is still not completely understood. Several theories have been advanced: 1) direct tissue destruction by Trypanosoma cruzi; 2) neurogenic theory; 3) anti-heart immune reactions; and 4) microvascular disease. We present herein a dynamic alternative hypothesis. We believe that the development of myocarditis is related to progressive and additive focal cellular necrosis, and associated reactive and reparative myocardial fibrosis and surrounding myocyte hypertrophy. These processes may be initiated and perpetuated by anti immune factors and alterations in the myocardial microcirculation. The destruction of the ganglion cells of the heart may be involved in the patho-clinical evolution of chronic Chagas' cardiopathy. This could imply future therapeutic strategies in the management of chronic Chagas'patients to enhance medical treatment and, hopefully, improve prognosis.

UNITERMS: Myocarditis. Chagas's disease.

\section{INTRODUCTION}

$\mathrm{C}$ hagas' disease, caused by the transmission of Trypanosoma cruzi, is one of the greatest public health problems faced by many Latin American countries, and in regions ranging from the southern United States to Argentina (53). The disease is characterized by three phases: acute, latent and chronic $(1,43)$. The most important visceral involvement is that of the heart. During

\section{Address for Correspondence:}

Marcos A. Rossi

Departamento de Patologia - Faculdade de Medicina de

Ribeirão Preto - Universidade de São Paulo

Ribeirão Preto - SP - Brasil - CEP 014049-900 the acute phase the degree of myocardial involvement varies from slight asymptomatic or oligosymptomatic to serious, even fatal, forms. These serious forms are not frequent, making up just $3.5 \%$ of the cases. During the initial stages of the chronic phase the patient may be asymptomatic or show some symptoms related with heartbeat disturbance; during intermediate stages, clinical manifestation persists or intensifies, heart enlargement may be detected, varying from slight to moderate; in the final stage heart enlargement is more pronounced plus serious congestive cardiac failure, thromboembolic phenomenon and serious arrhythmia. Sudden death is a constant risk at any stage of the disease. The latent phase is the intermediate period separating the acute and chronic ones, and is usually long lasting (from 10 to 20 years). Little is known regarding the clinical pathological manifestations. 
The pathology reflects the importance of cardiac involvement in Chagas' disease (20). During the acute phase, the heart is globous and flaccid; regions of myocytic necrosis and myocellular degeneration can be observed microscopically with intense infiltrated lymphomononuclear inflammation associated with exudative phenomenon and myofiber parasitism. During the chronic phase, cardiopathy is polymorph, with varying degrees of hypertrophy and dilation. Apical aneurysm may or may not be present. A focused or diffuse infiltrated lymphomononuclear inflammation may be microscopically observed, plus regions of myocytic necrosis and degeneration of myocardial cells, interstitial fibrosis of varying degrees and rare fibers with intracellular parasites. The Chronic Chagas' Myocarditis Pathogenesis is, however, not completely understood. Several different types of treatment have been proposed.

\section{DIRECT TISSUE LESION BY TRYPANOSOMA CRUZI}

Lesions may be caused by continued invasion of the myocardium, by localized liberation of toxins, or both. Insignificant parasitemia levels and the occasional finding of parasitic pseudocysts are arguments against the theory that myocardial lesions are directly correlated to the presence of the parasites. However a possible relationship between the presence of the $T$. cruzi immunogens and the intensity of inflammatory infiltrate has been observed in autopsied chronic Chagas' patients, suggesting therefore that the parasite has a role in perpetuating chronic myocarditis (15).

\section{NEUROGENIC THEORY}

Chronic myocardiopathy caused by Chagas' disease can be considered as cardioneuropathy due to the destruction of the heart's parasympathetic ganglionic cells $(20,29)$. Histological studies show an accentuated reduction in the number of parasympathetic cardiac neurons in proportion to the alterations in heart pathologies $(20,29)$. These observations have been contested by researchers who have noticed an absence of neuronal lesion at the onset of the disease, and no relationship between the neuronal count and the disease's progress. Myocardial lesions and discrete ventricular dilation preceded parasympathetic functional heart abnormalities in Chagas' patients. However, results of recent functional studies have confirmed the occurrence of abnormalities of the regulating neural heart mechanisms in chronic Chagas' patients without cardiac insufficiency.

\section{ANTIMYOCARDIAL IMMUNOLOGICAL REACTIONS}

The action of self immune mechanisms has been held to be the main cause of chronic Chagas' myocarditis $(1,18,30,43)$.

Setting up an experimental model which could provide evidence in favor of this theory to allow reliable immunological handling would be extremely important. We have shown in a recent study that lab mice when chronically infected by $T$. cruzi were capable of rejecting syngenical hearts of new-born ear-transplanted animals (32). Transplanted syngenical heart rejection happened quicker than when compared to an allogenic situation. These observations were in complete contrast to normal or $T$. cruzi hyperimmunized syngenic receivers with transplanted organs, which lasted for months. The histological study of transplanted cardiac tissue in Chagas' mice revealed intense and persistent mononuclear inflammatory infiltrate, similar to that obtained under allogenic conditions, thus indicating the implication of cellular mechanisms.

A series of tests was carried out to determine the phenotype of those cells involved in syngenical heart rejection phenomena (Figure 1). T CD4 cell depletion in vivo, but not $\mathrm{CD} 8$ cells caused cell rejection to be halted, i.e. cardiac transplants survived in chronically infected mice treated with anti CD4 monoclonal antibody (32). Anti C24 monoclonal antibodies have been used successfully in similar experiments to show the tolerance induction in Langerhaus islets allotransplantation in mice, or allogenic heart transplants in rats $(44,45)$. In vivo studies with $\mathrm{T}$ CD4 lymphocyte from chronically infected mice by $T$. cruzi have shown that, injected in situ, it brings about the destruction of syngenic transplants of normal mice hearts (32). On the other hand, T CD8 cells or non T cells were ineffective. These results, when analyzed collectively, demonstrated that self reactivity is restricted to T CD4 cell division, in contrast to skin allogenic transplant rejection attributed to the T CD4 and CD8 lymphocytes $(6,19)$. The observation that the majority of $\mathrm{T}$ cells infiltrating the myocardium during the acute and chronic phases of the $T$. cruzi experimental infection, 


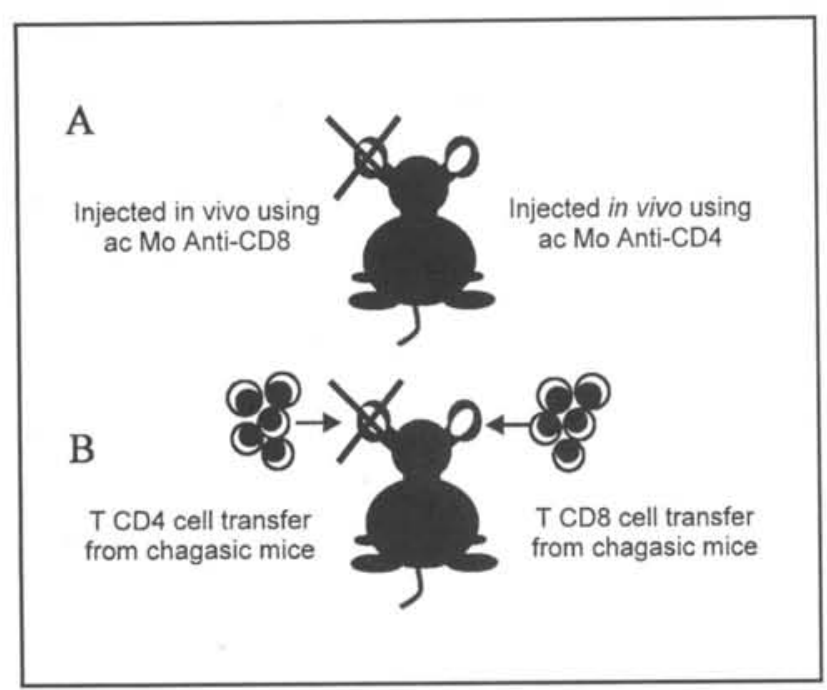

Figure 1. Schematic reproduction of transplanted heart rejection dependent on T CD4 lymphocytes. (A) Chronically infected mouse transplanted with syngenic hearts. Rejection is avoided by treatment with Anti-CD4 monoclonal antibody, but not by antiCD8. (B) Non infected control mouse transplanted using syngenic hearts. T CD4 splenic cells, but not CD8, from chronic syngenic Chagas' donors are capable of acutely rejecting implanted hearts

corresponding to T CD4 lymphocytes favors this theory. This also concurs with other specific self immune disease experimental models, where the T CD4 cells carry out an important role in inducing tissue lesions $(39,41)$. It has been shown that T CD4 lymphocytes modulate antibody production, macrophage activation, and induce lesions in the experimental trypanosomiasis cruzi $(16,24,35,38)$.

It is known that the expression CD4 correlates with the cell's capacity to recognize antigens connected with class II molecules $(12,47)$. As no formal demonstration exists that myocytes can express class II molecules in the membrane, it seems unlikely that T CD4 cells are responsible for the final cytotoxic effector activity. We have recently related that the red ruthenium strongly marks the myocytes' cytoplasmic components at the point of contact, or in close approximation of the macrophages, indicating altered areas of the plasmatic membrane with an increase in permeability. These observations suggest that the mononuclear cell with the appearance of activated macrophage would be the effector cell which injures the myocytes. In this case T CD4 lymphocytes would recognize the myocardial antigens together with the class II antigens expressed in resident macrophages or dendritic cells, activating the T CD4 cells, with a subsequent production of interleucin (46). Thus an inflammatory process would begin, inducing the destruction of the myocardial tissue.

An interesting question brought up from this data refers to self reacting T CD4 lymphocyte activation. The molecular mimetism between myocardium antigens and T. cruzi may be ultimately responsible (50).

However, $T$. cruzi hyperimmunized mice do not reject syngenical heart transplants. Apart from this the CD4 cells of these mice, injected in situ, do not destroy the implants and do not proliferate in vitro in the presence of heart antigens (32). Acute infection and large lesions of the target organ would be necessary to cause the rupture of the tissues' specific tolerance. As an example, during the acute phase of the disease T. cruz antigens would copy the myocardial cells and increase the tissue lesion induced by the immune response to the parasite (31). The policing activation of the $\mathrm{T}$ and $\mathrm{B}$ cells would play an important part during the $T$. cruzi infection's acute phase having an important role in the development a posteriori of the disease's self immunity . To date, we support the theory that extensive tissue lesions and self immune dysfunction during the acute phase, more than crossed reactivity between its own and T. cruzi antigens, would be absolutely essential for organ-specific self-immunity in the chronic phase to appear. Chronically T. cruzi infected isogenic mice show T CD4 lymphocytes responsive to myosin (33). The liberated myosin due to cellular lesion would be processed and shown by resident macrophages or by cells dendritic to the T CD4 cells which modulate antibody production, and by inducing macrophage activation and subsequent tissue lesion. Apart from this, evidence suggests that the T-cells play a part in the fibrosis pathogenesis, acting directly on the fibroblasts, by drawing up cytocins, or indirectly by amplifying macrophage activity (21).

These findings allow us to conclude that self immunity is the principle mechanism implied in the rejection of transplanted syngenic cardiac tissue in the ear of chronically $T$. cruzi infected mice. The similarity of the lesions to those observed in humans suggests that self immunity is involved in human Chagas' myocarditis pathogenesis. This may imply therapeutic strategies for re-establishing the chronic specific tolerance by treatment with anti-CD4 mononuclear antibodies, mediating energy or the suppression of responsive T CD4 cells.

Within this context, an important aspect to be taken into consideration is that related to those factors which contribute to the progression from the acute phase to the intermediate phase of Chagas' disease and to those factors involved in the progression from the intermediate phase to the disease's chronic phase. It has been proposed that 
damage to the suppressing immunological network could play a part in myocardial lesion pathogenesis, in both the acute and chronic phases $(2,42)$.

\section{MICROVASCULAR DISEASE}

It has been recently been claimed that microvascular abnormalities play a significant part in the pathogenesis of chronic Chagas' cardiopathy $(8,26,36,34,37,49)$. The focal nature of myocytolic necrosis associated with interstitial fibrosis and mononuclear inflammatory infiltrate in chronic Chagas' myocarditis suggests that the microcirculatory system may be at cause, i.e. the disease's primary location may be capable of causing focal necrosis in cells of discrete groupings. The involvement of small vessels has been previously related by only a few authors, referring to human Chagas' disease as well as the experimental field. Necrotizing arteritis has been observed in heart biopsies in cases of human Chagas' megaesophagus (5), and in the digestive tract of experimentally $T$. cruzi infected mice (28). Comparative studies of humans between Chagas' hearts and non Chagas' hearts show irregularities and constrictions of intramyocardial arteriolar vessels and extensive myocylitus with the group of Chagas' disease sufferers $(51,52)$. It was then proposed that the diffuse myocylitus observed in chronic Chagas' myocardiopathy would result in metabolic changes to the myocells due to the low intensity circulatory changes of short duration (52). Histotopographic study, comparing the microcirculatory system in Chagas' hearts and controls intravascular post-injection of an opaque medium, demonstrated focal Chagas' decapillarization, characterized by an accentuated reduction in nutrient filiforms, being the probable cause of focal myocytolytic necrosis (17).

Platelet thrombosis in small epi and intramyocardiac coronary vessels plus histochemical evidence of the presence of myocardial hypoxia focus were observed in mice chronically infected with the $T$. cruzi Colombia strain $(36,37)$. These findings lead us to believe that the consequences of the infection converge on the cardiac microvasculature, resulting in areas of hypoperfusion,

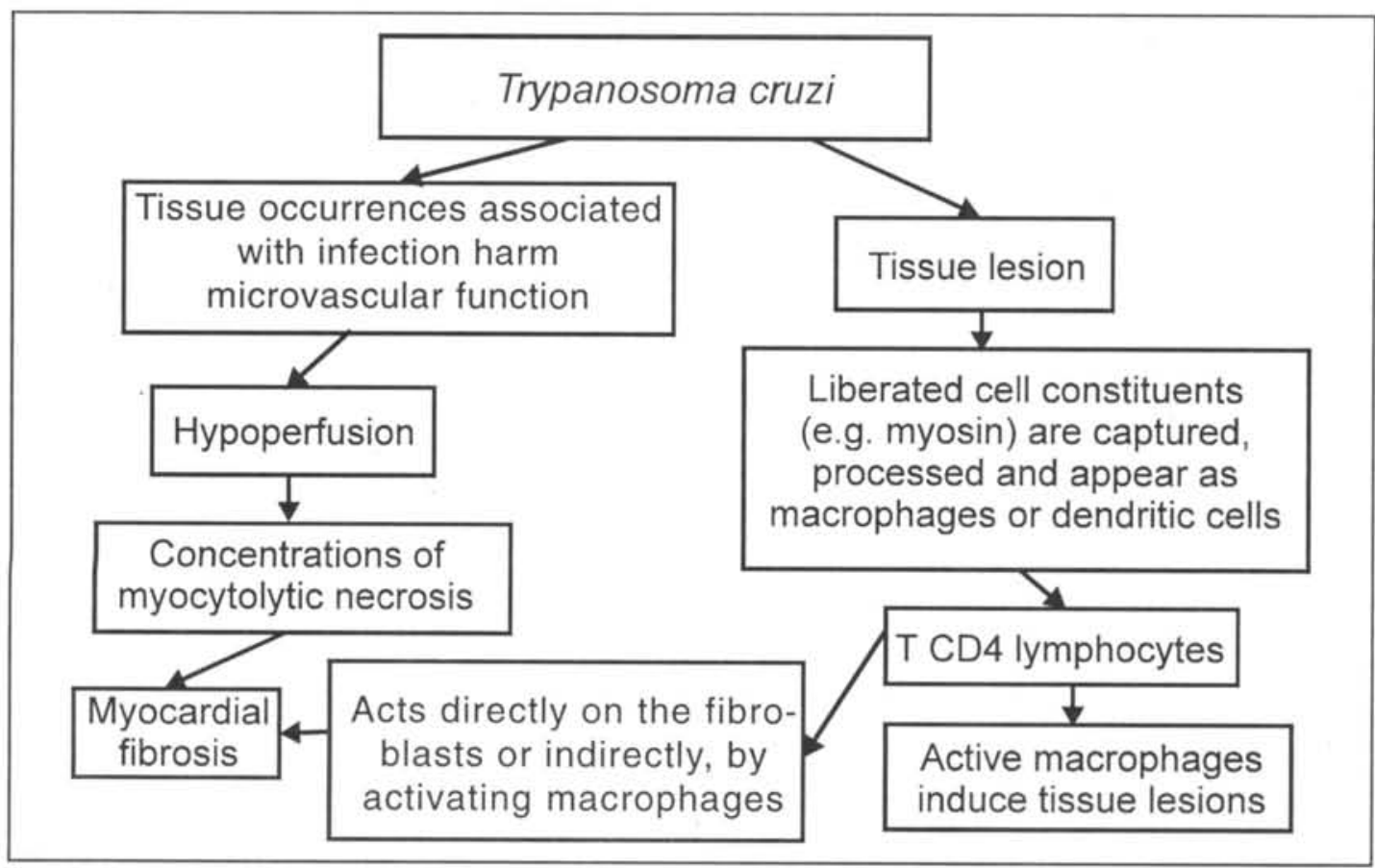

Figure 2. A theoretical schematic representation of the pathogenesis of chronic Chagas' myocarditis. Myocarditis' development is related to progressive and accumulated local cellular necrosis, associated with reparative and reactive interstitial fibrosis and circumjacent myocytaric hypertrophy. These processes begin and are perpetuated by self immune factors and by changes in myocardium microcirculation. 
regions of focal myocytolic necrosis, interstitial fibrosis and hypertrophy of the circumjacent cardiac muscle cells. Apart from this, the hypothesis has been put forward that the inflammatory infiltrate consisting predominantly of macrophages and lymphocytes contributes to the state of microvascular hypoperfusion of the secretion of A2 thromboxan and platelet aggregation and vessel spasm.

Microvascular spasm and microaneurism formation in coronary circulation were described in acute $T$. cruzi infection in mice (8) in a similar manner to that observed in other congestive myocardiopathy $(9,11)$. These microvascular changes were detected early on during the evolution of experimental Chagas' disease, before the onset of degeneration or myocardial fibrosis.

To back up the microvascular hypothesis it has been related that chronic administration of Verapamil, a calciumchannel blocking drug, produced a significant reduction in inflammation and myocardial fibrosis in T. cruzi infected mice, apart from a 10 times lower mortality rate during a 70-day observation period (27). Verapamil apparently maintains vascular perfusion by vasodilation as a consequence of its action on the smooth muscle cells and by an inhibiting effect on platelet aggregation (4). In vitro studies have shown infection related endothelial cell dysfunction and a subsequent increase in platelet reactivity (48). Interaction between platelets and damaged endothelium or the subendothelial surface may stimulate platelet derived growth factor. The finding of high levels of A2 thromboxan in acutely infected plasma would contribute to platelet aggregation increasing the focal microvascular spasm.
Recent scintillographic studies using Thallium-201 in chronic dilated cardiopathic Chagas' patients have demonstrated a decrease in myocardial perfusion $(14,23)$, a likely consequence of microvascular ischemia (29). Within this context myocardial perfusion decrease has been described in 15 to 30 day post $T$. cruzi infected mice, radiographically evaluated using the 19-Iodine-3.3dimethyl-18 nonadecenoic fatty acid (49).

\section{THEORY}

In this present work we have presented an alternative hypothesis concerning chronic Chagas' myocarditis pathogenesis development is related to progressive and accumulative focal cellular necrosis, associated with distributive and reactive interstitial fibrosis and circumjacent myocytic hypertrophy. These processes are initiated and perpetuated by self immune factors and by alterations to myocardial microcirculation (Fig. 2). The autonomous nervous system's intrinsic alterations are implicated in the global context of the clinical-pathological evolution of chronic Chagas' cardiopathy. The proposed physiopathogenic mechanism would imply future therapeutic strategy for treating chronic Chagas' patients, enhancing medical care and treatment and, hopefully, improving prognosis.

\section{Resumo}

A patogênese da miocardite chagásica crônica permanece incompletamente compreendida. Diferentes hipóteses têm sido propostas: (1) lesão direta do tecido pelo Trypanosoma cruzí, (2) teoria neurogênica; (3) reaçōes imunológicas antimiocárdio; e (4) doença microvascular. Apresentamos, no presente trabalho, uma hipótese alternativa. Acreditamos que o desenvolvimento da miocardite está relacionado à necrose celular focal progressiva e acumulativa, associada à fibrose intersticial reparativa e reativa e hipertrofia miocitária circunjacente. Esses processos seriam iniciados e perpetuados por fatores autoimunes e alteraçōes na microcirculação do miocárdio. As alteraçōes intrínsecas do sistema nervoso autônomo estariam implicadas no contexto global da evolução clínico-patológica da cardiopatia chagásica crônica. O mecanismo fisiopatogênico proposto teria implicaçōes em futuras estratégias terapêuticas no tratamento do paciente chagásico crônico visando otimizar o tratamento médico e auspiciosamente melhorar o prognóstico. 


\section{REFERENCES}

1. ANDRADE, Z.A. - Mechanisms of myocardial damage in Trypanosoma cruzi infection. In: Ciba Foundation Symposium 99. Cytopathology of Parasitic Diseases, Ciba Foundation Symposium 99. London: Pitmann Books, 1983. p. 214-33.

2. ANDRADE, Z.A.; ANDRADE, S.G. \& SADIGURSKY, M. - Enhancement of chronic Trypanosoma cruzi myocarditis in dogs treated with low doses of cyclosphosphamide. Am J Pathol 127:467-73, 1987.

3. BEN YOUNÈS-CHENNOUFI, A.B.; SAID, G.; EISEN, H.; DURAND, A. \& HONTEBEYRIE-JOSKOWICZ, M. Cellular immunity to Trypanosoma cruzi is mediated by helper T cells (CD4+). Trans Roy Soc Trop Med Hyg 82:849, 1988.

4. BONADONNA, G.; LECHI, C.; CORRADINI, P.; SINIGAGLIA, D.; TOGNI, P.D. \& MIROSLAWA, G. Verapamil inhibits platelet aggregation by a calcium independent mechanism. Thromb Haemost 56:308-10, 1986.

5. BRITO, T. \& VASCONCELOS, E. - Necrotizing arteritis in megaesophagus. Histopathology of ninety-one biopsies taken from the cardia. Rev Inst Med Trop São Paulo 1:195-206, 1959.

6. COBBOLD, S.P.; JAYASURIYA, A.; NASH, A.; PROSPERO, T.D. \& WALDMANN, H. - Therapy with monoclonal antibodies by elimination of T-cell subsets in vivo. Nature 312:548-51, 1984.

7. DAVILA, D.F.; ROSSELL, R.O. \& DONIS, J.H. - Cardiac parasympathetic abnormalities: cause or consequence of Chagas' heart disease? Parasitol Today 5:327-9, 1989.

8. FACTOR, S.M.; CHO, S.; WITTNER, M. \& TANOWITZ, $\mathrm{H}$. - Abnormalities of the coronary microcirculation in acute murine Chagas' disease. Am J Trop Med Hyg 34:246-53, 1985.

9. FACTOR, S.M.; MINASE, T.; CHO, S.; FEIN, F.; CAPASSO, J.M. \& SONNENBLICK, E.H. - Coronary microvascular abnormalities in the hypertensive-diabetic rat: a primary cause of cardiomyopathy? Am J Pathol 116:9-20, 1984.

10. FACTOR, S.M.; OKUN, E.M. \& MINASE, T. - Capillary microaneurysms in the human diabetic heart. $\mathbf{N}$ Engl J Med 302:384-8, 1980.

11. FACTOR, S.M. \& SONNENBLICK, E.H. - Hypothesis: is congestive cardiomyopathy caused by a hyperreactive myocardial microcirculation (microvascular spasm)? Am J Cardiol 50:1149-52, 1982.

12. GAY, D.; MADDON, P.; SEKALY, R.; TALLE, M.A.; GODFREY, M.; LONG, E.; GOLDSTEIN, G.; CHESS, L.; AXEL, R.; KAPPLER, J. \& MARRACK, P. - Functional interaction between human $\mathrm{T}$ cell protein $\mathrm{CD} 4$ and the major histocompatibility complex HLA-DR antigen. Nature 328:626-9, 1987.

13. GUZZETTI, S.; IOSA, D.; PECIS, M.; BONURA, L.; PROSDOCIMI, M. \& MALLIANI, A. - Impaired heart rate variability in patients with chronic Chagas' disease. Am Heart J 121:1727-1734, 1991.

14. HAGAR, J.M.; TUBAU, J.F. \& RAHIMTOOLA, S.H. Chagas' heart disease in the USA: thallium abnormalities mimic coronary artery disease. Circulation 84:631, 1991.

15. HIGUCHI, M.L.; BRITO, T.; REIS, M.M.; BARBOSA, A.; BELLOTTI, G.; PEREIRA-BARRETO, A.C. \& PILLEGI, F. - Correlation between Trypanosoma cruzi parasitism and myocardial inflammatory infiltrate in human chronic chagasic myocarditis: light microscopy and immunohistochemical findings. Cardiovasc Pathol 2:101-6, 1993.

16. HONTEBEYRIE-JOSKOWICS, M.; SAID, G.; MILLON, G.; MARCHALL, G. \& EISEN, H. - L3T4+ T cells able to mediate parasite-specific delayed type hypersensitivity play a role in the pathology of experimental Chagas' disease. Eur J Immunol 17:1027-33, 1987.

17. JÖRG, M.E. - Tripanosomiasis cruzi; anarquia angiotopográfica por descapilarización mesenquimorreactiva, cofactor patogénico de la miocardiopatia crónica. Pren Med Argent 61:94-106, 1974.

18. KIERSZENBAUM, F, - Autoimmunity in Chagas' disease. J Parasitol 72:201-11, 1986.

19. KITAGAWA, S.; SATO, S.; HORI, S.; HAMAOKA, T. \& FUJIWARA, H. - Induction of anti-allo-class $\mathrm{I} H$-2 tolerance by inactivation of $\mathrm{CD} 8+$ helper $\mathrm{T}$ cells, and reversal of tolerance through introduction of third-party helper T cells. J Exp Med 172:105-13, 1990.

20. KÖBERLE, F. - Chagas' disease and Chagas' syndromes: the pathology of American trypanosomiasis. Adv Parasitol 6:63-116, 1968.

21. KOVACS, E.J. - Fibrogenic cytokines: the role of immune mediators in the development of scar tissue. Immunol Today 12:17-23, 1991.

22. LOPES, E.R. \& TAFURI, W.L. - Involvement of the autonomic nervous system in Chagas' heart disease. Rev Soc Bras Med Trop 16:206-12, 1983.

23. MARIN-NETO, J.A.; MARZULLO, P.; MARCASSA, C.; GALLO, L.JR.; MACIEL, B.C.; BELLINA, C.R.L. \& ABBATE, A. - Myocardial perfusion abnormalities in chronic Chagas' disease as detected by thallium-201 scintigraphy. Am J Cardiol 69:780-4, 1992.

24. MINOPRIO, P.; EISEN, H.; JOSKOWICZ, M.; PEREIRA, P. \& COUTINHO, A. - Suppression of polyclonal antibody production in Trypanosoma cruzi-infected mice by treatment with anti-L3T4 antibodies. J Immunol 139:545-50, 1987.

25. MINOPRIO, P.; ITOHARA, S.; HEUSSER, C.; TONEGAWA, S. \& COUTINHO, A. - Immunobiology of murine $T$. cruzi infection: the predominance of parasitenonspecific responses and the activation of TCRI T cells. Immunol Rev 112:183-207, 1989.

26. MORRIS, S.A.; TANOWITZ, H.B.; WITTNER, M. \& BILEZIKIAN, J.P. - Pathophysiological insights into the cardiomyopathy of Chagas' disease. Circulation 82:19009, 1990.

27. MORRIS, S.A.; WEISS, L.M.; FACTOR, S.; BILEZIKIAN, J.P.; TANOWITZ, H.B. \& WITTNER, M. - Verapamil ameliorates clinical, pathological and biochemical 
manifestations of experimental chagasic cardiomyopathy in mice. J Am Coll Cardiol 14:782-9, 1989.

28. OKUMURA, M.; BRITO, T.; PEREIRA DA SILVA, L.H.; CARVALHO-DA-SILVA, A. \& CORREA-NETO, A. - The pathology of experimental Chagas' disease in mice. I. Digestive tract changes with special reference to necrotizing arteritis. Rev Inst Med Trop São Paulo 2:17-8, 1960.

29. OLIVEIRA, J.S.M. - A natural model of intrinsic heart nervous system denervation: Chagas' cardiopathy. Am Heart J 110:1092-8, 1985.

30. RIBEIRO DOS SANTOS, R. \& ROSSI, M.A. Imunopatologia. In: Cançado, J.R. \& Chuster, M. eds. Cardiopatia Chagásica. Fundação Carlos Chagas. Belo Horizonte, 1985. p. 10-22.

31. RIBEIRO DOS SANTOS, R. \& HUDSON, L. - Trypanosoma cruzi: immunological consequences of parasite modification of host cells. Clin Exp Immunol 30:36-41, 1980.

32. RIBEIRO DOS SANTOS, R.; ROSSI, M.A.; LAUS, J.L.; SANTANA SILVA, J.; SAVINO, W. \& MENGEL, J. - AntiCD4 abrogates rejection and reestablishes long-term tolerance to syngeneic newborn hearts grafted in mice chronically infected with Trypanosoma cruzi. J Exp Med 175:29-39, 1992 .

33. RIZZO, L.V.; CUNHA-NETO, E. \& TEIXEIRA, A.R.L. Autoimmunity in Chagas' disease: specific inhibition of reactivity of CD4+ T cells against myosin in mice chronically infected with Trypanosoma cruzi. Infect Immun 57:26404, 1989.

34. ROSSI, M.A. - Microvascular changes as a cause of chronic cardiomyopathy in Chagas' disease. Am Heart J 120:2336, 1990.

35. ROSSI, M.A. - Myocardial damage in Trypanosoma cruzi myocarditis: a role for macrophages. Can J Cardiol 6:293$8,1990$.

36. ROSSI, M.A. \& CAROBREZ, S.G. - Experimental Trypanosoma cruzi cardiomyopathy in BALB/c mice: histochemical evidence of hypoxic changes in the myocardium. Br J Exp Pathol 66:155-60, 1985.

37. ROSSI, M.A.; GONÇALVES, S. \& RIBEIRO DOS SANTOS, R. - Experimental Trypanosoma cruzi cardiomyopathy in BALB/c mice. The potential role of intravascular platelet aggregation in its genesis. Am J Pathol 114:209-16, 1984.

38. RUSSO, M.; STAROBINAS, N.; MINOPRIO, P.; COUTINHO, A. \& HONTEBEYRIE- JOSKOWICZ, M. Parasitic load increases and myocardial inflammation decreases in Trypanosoma cruzi-infected mice after inactivation of helper T cells. Ann Immunol (Inst Pasteur) 139:225-36, 1988.

39. SAKAGUCHI, S.; SAKAGUCHI, N. - Thymus and autoimunity. Transplantation of the thymus from cyclosporin A-treated mice causes organ-specific autoimmune disease in athymic nude mice. J Exp Med 167:1479-85, 1988.

40. SAKAGUCHI, S. \& SAKAGUCHI, N. - Organ-specific autoimmune disease induced in mice by elimination of $\mathrm{T}$ cell subsets. V. Neonatal administration of cyclosporin A causes autoimmune disease. J Immunol 142:471-80, 1989.
41. SAKAGUCHI, S. \& SAKAGUCHI, N. - Thymus and autoimmuity: capacity of the normal thymus to produce pathogenic self-reactive $\mathrm{T}$ cells and conditions required for their induction of autoimmune disease. J Exp Med 172:53745, 1990.

42. SANTANA SILVA, J. \& ROSSI, M.A. - Intensification of acute Trypanosoma cruzi myocarditis in BALB/c mice pretreated with low doses of cyclosphosphamide or gamma irradiation. J Exp Path 71:33-9, 1990.

43. SANTOS-BUCH, C.A. \& ACOSTA, A.M. - Pathology of Chagas' disease. In: Tizard, I., ed. Immunology and Pathogenesis of Trypanosomiasis. Boca Raton, Fla: CRC Press Inc, 1985. p. 145-84.

44. SHIZURU, J.A.; GREGORY, A.K.; CHAO, C.T.B \& FATHMAN, C.G. - Islet allograft survival after a single course of treatment of recipient with antibody to L3T4. Science 237:278-80, 1987.

45. SHIZURU, J.; SEYDEL, J.; FLAVIN, T.F.; WU, A.; KONG, C.; HOYT, E.; FUJIMOTO, N.; BILLINGHAM, M.; STARNES, V. \& FATHMAN, C. - Induction of donor specific unresponsiveness to cardiac allografts in rats by pretransplant anti-CD4 monoclonal antibody therapy. Transplantation 50:366-73, 1990.

46. SING, R.P.; PATARCA, R.; SCHWARTZ, J.; SINGH, P. \& CANTOR, H. - Definition of a specific interaction between the early $\mathrm{T}$ lymphocyte activation 1 (Eta-1) protein and murine macrophage in vitro and its effect upon macrophage in vivo. J Exp Med 171:1931-42, 1990.

47. SWAIN, S.L. - T cell subsets and the recognition of MHC class. Immunol Rev 74:129-38, 1983.

48. TANOWITZ, H.B.; BURNS, E.R.; SINHA, K.A.; KAHN, N.N.; MORRIS, S.A.; FACTOR, S.M.; HATCHER, V.B.; BILEZEKIAN, J.P.; BAUM, S.G. \& WITTNER, M. Enhanced platelet adherence and aggregation in Chagas' disease: a potential pathogenic mechanism for cardiomyopathy. Am J Trop Med Hyg 43:274-81, 1990.

49. TANOWITZ, H.B.; MORRIS, S.A.; FACTOR, S.M.; WEISS, L.M. \& WITTNER, M. - Parasitic diseases of the heart. I: acute and chronic Chagas' disease. Cardiovasc Path 1:7-15, 1992.

50. TEIXEIRA, A.R.L.; TEIXEIRA, L. \& SANTOS-BUCH, C.A. - The immunology of experimental Chagas' disease. IV. The production of lesions in rabbits similar to those of chronic Chagas' disease in man. Am J Pathol 80:163-77, 1975.

51. TORRES, C.M. - Arteriolosclerose das finas ramificações arteriais do miocárdio (coronarite chagásica) e miocitólise focal do miocárdio na cardiopatia chagásica crônica. Hospital 54:597-610, 1958.

52. TORRES, C.M. - Miocitólise e fibrose do miocárdio na doença de Chagas. Mem Inst Oswaldo Cruz 58:161-82, 1960.

53. WORLD HEALTH ORGANIZATION EXPERT COMMITTEE. Chagas' disease. In: World Health Organization Technical Report Series 697. Geneva: WHO, 1984:50-5. 